\title{
Academia in Svalbard: an increasingly important role for research and education as tools for Norwegian policy
}

\author{
Ole Arve Misund
}

University Centre in Svalbard, Longyearbyen, Norway; National Institute of Nutrition and Seafood Research, Bergen, Norway; Department of Biology, University of Bergen, Bergen, Norway

\section{ABSTRACT}

Svalbard, a High-Arctic archipelago over which Norway practises sovereignty in accordance with the terms of the Svalbard Treaty, has become an increasingly important area for Arctic research and higher education. There are four more or less permanent settlements with substantial research infrastructure, and a few manned observatories for special purposes. Several Norwegian and foreign research institutions have established stations and installations in the archipelago. With coal mining activity scaling down because of economic difficulties and lack of political support for subsidies, Norwegian policy will prioritize research and higher education as a way of maintaining Norwegian settlements in Svalbard. I give an overview of the institutions, organizations and facilities for research and higher education in Svalbard, and discuss the increasingly important role of research and education in Norwegian Svalbard policy.

\section{KEYWORDS}

Arctic; higher education;

University Centre in

Svalbard; Svalbard Treaty;

geopolitics; climate research

\section{ABBREVIATIONS}

NPI: Norwegian Polar Institute; SIOS: Svalbard Integrated Arctic Earth Observing System; SNSK: Store Norske Spitsbergen Kulkompani; SSC: Svalbard

Science Centre; SSF:

Svalbard Science Forum; UiT University of Troms $\varnothing$ - the Arctic University of Norway; UNIS: University Centre in

Svalbard
Recent developments in Svalbard pose a challenge to the Norwegian government, which aims to keep a dominant Norwegian presence in the archipelago, which it administers in accordance with the terms of the Svalbard Treaty of 1925. The treaty recognizes Norwegian sovereignty over Svalbard, but gives equal rights to the citizens of all the signatory nations (45 as of 2016) to reside there without visas and to engage in commercial activities. The coal mining activity that has for many years been a cornerstone of permanent Norwegian settlement in Longyearbyen is scaling down, and alternative activities must be found to maintain the Norwegian community. Developing Longyearbyen as a modern family community in the High Arctic has long been one of the main priorities of the Norwegian government's Svalbard policy. Expansion in the public and private sectors is now needed to compensate for the loss of workplaces within the mining industry. The Strategic business plan for Svalbard (Svalbard Business Association 2014), developed by the Business Association of Svalbard in cooperation with the Longyearbyen Town Council, suggests that the education and research sector could double in the years to come.

Scientific activities have increased in Svalbard during the last decades, and several Norwegian and foreign institutions have established research stations and installations in the archipelago. A recent survey shows that visits to Svalbard for the purpose of research totalled 61000 person days in 2014, of which Norwegian researchers contributed approximately half (Aksnes \& Rørstad 2015). Nevertheless, research plays a limited role in maintaining permanent settlements, as most of the activities involve short-term visits by researchers. Exceptions include the staff at UNIS, who live in Svalbard year-round. The NPI, the SSF and a few other research organizations also have employees stationed in Svalbard all year.

The Norwegian government's goals and strategies for its Svalbard policy, as laid out in two white papers (NMJ 2009, 2016) presented to Norway's parliament, the Storting, have included consistent and firm enforcement of Norwegian sovereignty through proper observance of the Svalbard Treaty and control to ensure compliance with the Treaty. Maintenance of peace and stability in the area is prioritized, along with preservation of the area's distinctive natural wilderness. The government sees the maintenance of Norwegian communities in the archipelago as central to enforcing sovereignty through civilian presence.

Here I briefly describe the scientific infrastructure, organizations and activities in the communities in Svalbard and discuss their role in relation to Norwegian policy for research, environmental 
protection and sovereignty. Specifically, I discuss the potential for research and educational organizations to take a larger role in the communities where coal mining is being curtailed.

\section{Svalbard settlements}

For centuries, Svalbard has been an arena for expedition-based polar exploration and resource exploitation by Dutch, Russian, Norwegian, Swedish, British, French and others (Arlov 2007; Avango et al. 2011). Exploitation of biological resources started in the early 17 th century with whaling, followed by hunting and trapping after 1700 . These activities mainly took the form of summer expeditions, but much of the hunting and trapping has been carried out by individuals operating from scattered, rather primitive and isolated stations in the coastal areas of Svalbard (Reymert \& Moen 2015).

Scientific exploration took off during the 19th century and revealed, among other things, valuable mineral deposits. Coal mining developed after 1900 and required year-round presence (Hacquebord \& Avango 2009). To produce coal from the relatively rich and easily accessible coal deposits, five more or less permanent villages were established in Svalbard: Ny-Ålesund (Norwegian), Pyramiden (Russian), Longyearbyen (Norwegian), Svea (Norwegian) and Barentsburg (Russian) (Arlov 2007; Fig. 1). Operational difficulties led to closure of the coal mine in Ny-Ålesund in 1962, and Pyramiden was abandoned in 1998.

Coal mining operations are ongoing in Longyearbyen and Sveagruva by the Norwegian mining company SNSK and in Barentsburg by the Russian company Trust Arktikugol. However, low prices on the international coal market are forcing the coal mining companies to reduce their activity. In addition, there is political momentum to reduce coal mining on account of the contribution of coal to $\mathrm{CO}_{2}$ emissions to the atmosphere (Helgesen et al. 2015).

The former coal-mining village of $\mathrm{Ny}$-Ålesund (Figs. 1, 2) has been transformed into a base for international High-Arctic research. It is run by the Norwegian limited company Kings Bay, which facilitates Arctic field stations for polar research institutes from 11 nations (Table 1). In winter, the village is maintained by a staff of 25 , employed on short-term contracts only, with a maximum residence time of four years. There are no families and no children in the village. Cruise vessels are allowed to dock subject to permission. Transport to and from Longyearbyen is mainly by plane (twice a week), or more infrequently by helicopter or boat. Twenty-nine per cent of the research effort (person-years) by Norwegian research institutions active in Svalbard was carried out in Ny-Ålesund in 2014 (Fig. 3).

With a population of 2100 (Bjørnsen \& Johansen 2014), Longyearbyen is the northernmost family community in the world. The town has fully developed infrastructure - international airport, harbour

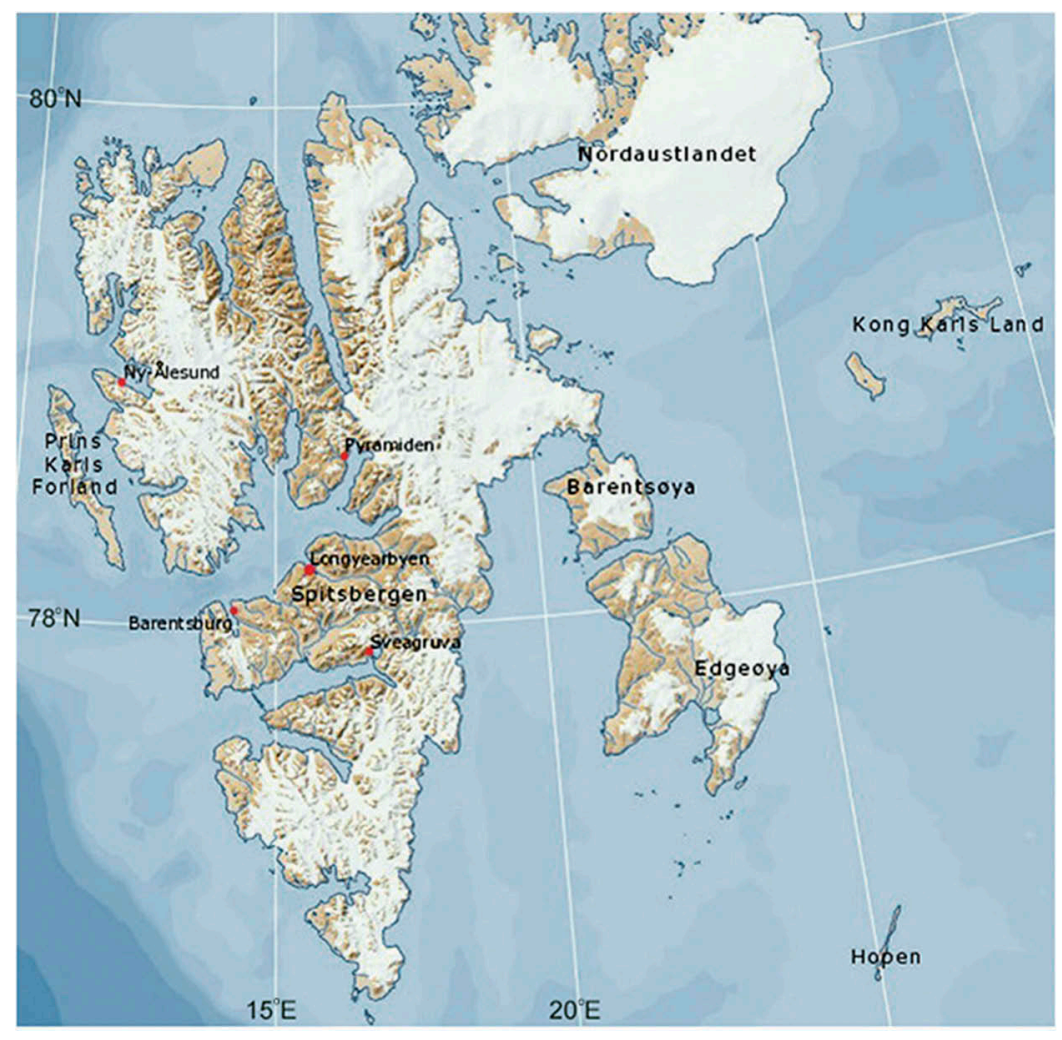

Figure 1. The Svalbard Archipelago and its permanent settlements (red dots). 


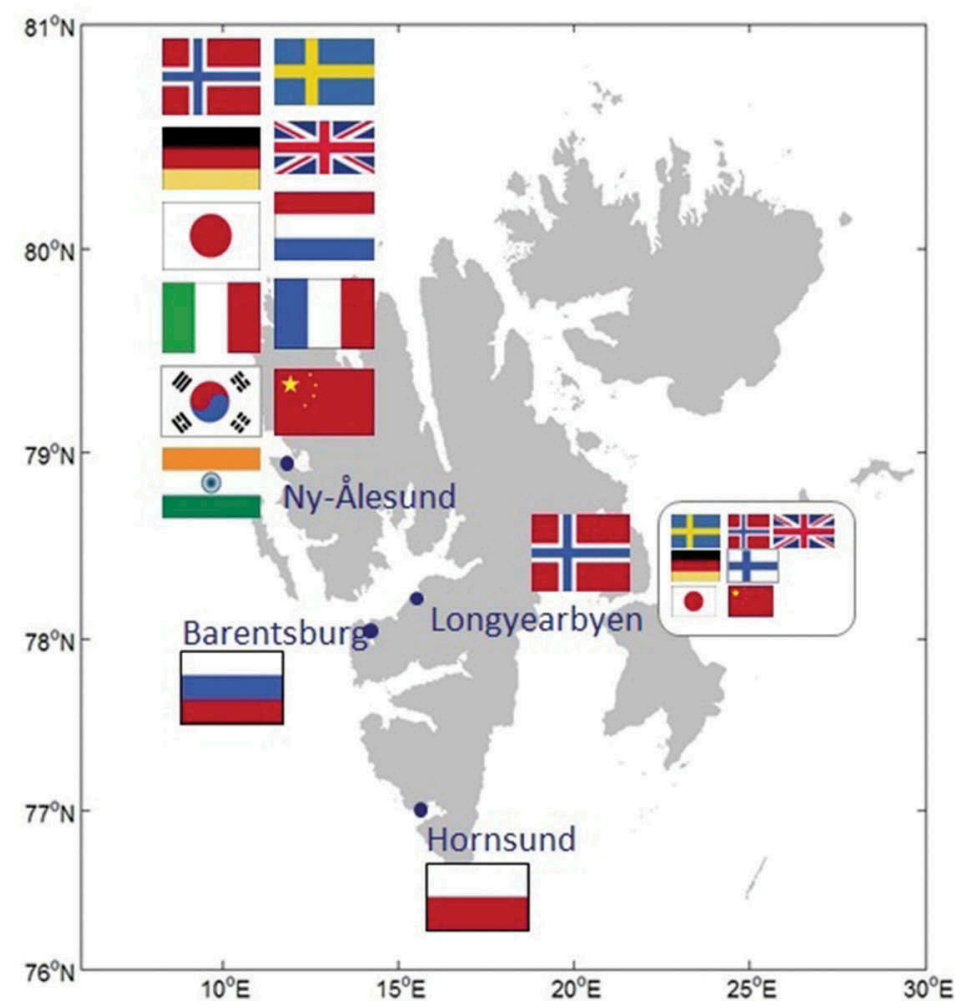

Figure 2. Nations with various education and research activities in the settlements in Svalbard.

Table 1. Research stations and observatories in Ny-Ålesund (source: http://kingsbay.no/research/research_stations/).

\begin{tabular}{|c|c|c|c|c|}
\hline Station & Organization & Country & Year & Research topics \\
\hline Rabben & $\begin{array}{l}\text { National Institute for Polar } \\
\text { Research }\end{array}$ & Japan & 1990 & $\begin{array}{l}\text { Arctic environment (atmosphere physics, terrestrial } \\
\text { biology, oceanography, glaciology, meteorology) }\end{array}$ \\
\hline $\begin{array}{l}\text { National Environment Research } \\
\text { Council }\end{array}$ & British Antarctic Survey & UK & 1991 & Earth and life sciences \\
\hline Koldeway & Alfred Wegener Institute & Germany & 1991 & Biology, chemistry, geology, atmospheric physics \\
\hline $\begin{array}{l}\text { Network for the Detection of } \\
\text { Atmospheric Composition Change } \\
\text { observatory }\end{array}$ & Alfred Wegener Institute & Germany & & Atmospheric physics, chemistry \\
\hline VLBI - antenna & Norwegian Mapping Authority & Norway & 1992 & Geodesy \\
\hline Arctic Centre & University of Groningen & Netherlands & 1995 & Ecology \\
\hline Dirigibile Italia & National Research Council of Italy & Italy & 1997 & Environmental research, climate research \\
\hline Charles Rabot Base & $\begin{array}{l}\text { French Polar Institute Paul Émile } \\
\text { Victor }\end{array}$ & France & 1999 & Atmospheric science, life sciences \\
\hline Jean Corbel & $\begin{array}{l}\text { French Polar Institute Paul Émile } \\
\text { Victor }\end{array}$ & France & 1999 & Atmospheric science \\
\hline Sverdrup & NPI & Norway & 1999 & Environment/ecosystem research \\
\hline Zeppelin & $\begin{array}{l}\text { NPI and Norwegian Institute for } \\
\text { Air Research }\end{array}$ & Norway & & Atmospheric chemistry \\
\hline Dasan & Korean Polar Research Institute & Korea & 2002 & $\begin{array}{l}\text { Environmental research, geomorphology, } \\
\text { hydrology }\end{array}$ \\
\hline AWIPEV & $\begin{array}{l}\text { Alfred Wegener Institute /French } \\
\text { Polar Institute Paul Émile Victor }\end{array}$ & $\begin{array}{l}\text { France and } \\
\text { Germany }\end{array}$ & 2003 & $\begin{array}{l}\text { Joint logistical operation of French and German } \\
\text { stations }\end{array}$ \\
\hline Yellow River & $\begin{array}{l}\text { Chinese Arctic and Antarctic } \\
\text { Administration }\end{array}$ & China & 2004 & $\begin{array}{l}\text { Meteorology, space-earth measurements, } \\
\text { glaciology, marine ecosystem, Arctic } \\
\text { environment }\end{array}$ \\
\hline Kings Bay Marine Laboratory & Kings Bay & Norway & 2005 & Marine laboratory \\
\hline Himadri & $\begin{array}{l}\text { National Centre for Antarctic \& } \\
\text { Ocean Research }\end{array}$ & India & 2008 & Marine ecosystems, atmospheric science, pollution \\
\hline $\begin{array}{l}\text { Amundsen-Nobile Climate Change } \\
\text { Tower }\end{array}$ & National Research Council of Italy & Italy & 2009 & Atmospheric boundary layers \\
\hline
\end{tabular}

facilities, bank, church, hospital, hotels, school, shops, advanced telecommunications and so on. The community is among the most international in Norway, with $22 \%$ of the population representing 39 nations other than Norway (Bjørnsen \& Johansen 2014). There is nearly $100 \%$ employment, and $70 \%$ of the population is younger than 45 years. Average residence time is four to five years. Of the person-years of employment produced in Svalbard in 2014, coal mining represented $34 \%$, the public sector $25 \%$, education and science $24 \%$ and travel and leisure $17 \%$ (Bjørnsen \& Johansen 2014). Out of the total annual 


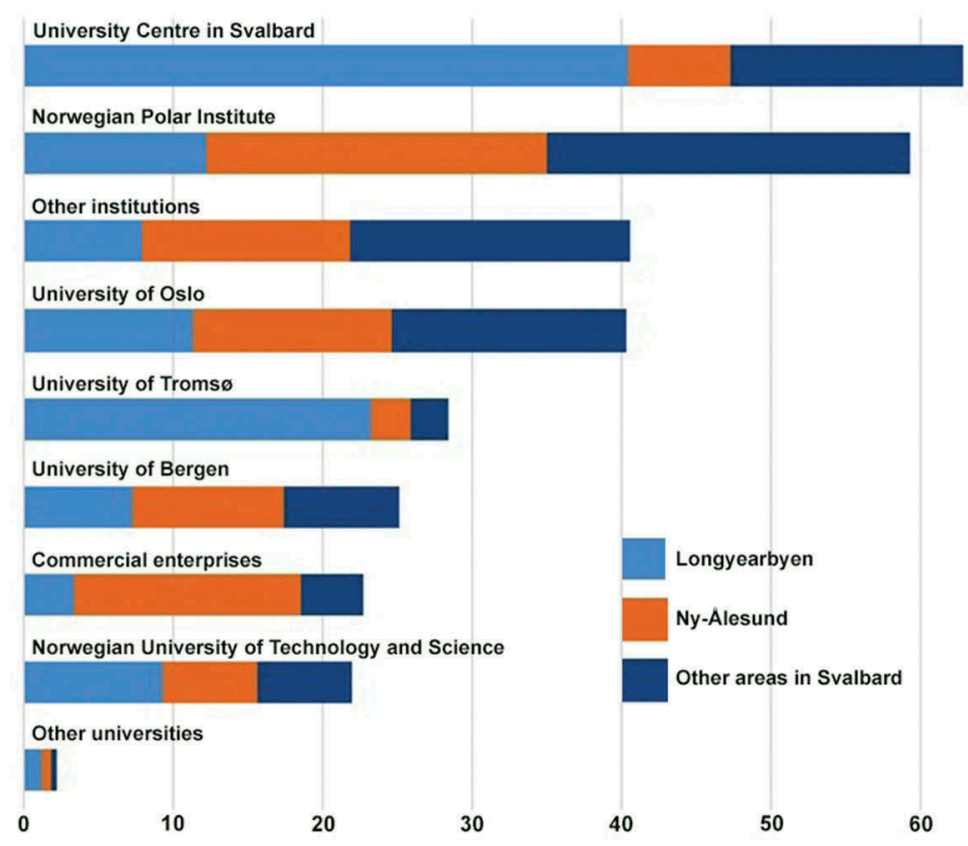

Figure 3. The research activity (in person-years) of the organizations active in Ny-Ålesund, Longyearbyen and other sites in Svalbard in 2014.

business revenue of about 500 million EUR, coal mining contributed $45 \%$, education and science $22 \%$, the public sector $21 \%$ and travel and leisure 12\% (Bjørnsen \& Johansen 2014). Since 2015, this distribution has been changing because of falling prices on the international coal market and their consequences for the local mining company. Thirtynine percent of the research effort by Norwegian academic institutions active in Svalbard was carried out in Longyearbyen in 2014 (Fig. 3).

The SSC is a spectacular edifice located centrally in Longyearbyen (MacKeith 2006). It houses UNIS, the Svalbard division of the NPI, the SSF and the Svalbard Museum. Several other academic organizations such as the UiT, the Norwegian University of Science and Technology, SINTEF, the Institute of Marine Research, the Nansen Environmental and Remote Sensing Centre, the Japanese National Institute of Polar Research and the Norwegian Scientific Academy for Polar Research have an office - alone or shared - at the SSC. The first building phase of the SSC was completed in 1996 and is owned by UNIS, whereas Phase II $\left(12000 \mathrm{~m}^{2}\right.$, opened in 2006) is owned by Statsbygg, Norway's government property management firm, which rents out facilities to the other organizations. The SSC was evaluated in 2014, and both the building and the societal value of the project were rated high (Anonymous 2014).

In Sveagruva, SNSK still operates a coal mine, but the SNSK board has decided to suspend mining operations there, a decision recently supported by the company's owner, the Norwegian government.
Still, there will be some activity in Sveagruva to maintain the facilities. Use of Sveagruva's infrastructure is rapidly shifting towards educational, research, and tourism activities rather than coal mining.

The Russian settlement of Barentsburg has about 400 permanent residents. Trust Arktikugol operates a coal mine; there is infrastructure for Russian research institutions, and a hotel that is open for tourists. A Russian Governor oversees activities in the town, but Norwegian law prevails and the Governor of Svalbard is ultimately in charge, as in all of Svalbard. Barentsburg can be reached by boat, helicopter or (in winter) snowmobile.

\section{Higher education and research}

UNIS has become the dominating research and higher education organization in Svalbard. UNIS's research activity corresponded to a total of more than 60 person-years in 2014, more than any other academic organization active in Svalbard (Fig. 3). This is also reflected in the Research in Svalbard database (see below), in which UNIS is the organization with the largest project portfolio (Fig. 4).

About 115 scientific, technical, and administrative staff, and $\mathrm{PhD}$ students and postdoctoral fellows with permanent addresses in Longyearbyen are affiliated with UNIS. There are an additional 38 adjunct professors in $20 \%$ positions and about 160 guest lecturers each year. About 700 students took courses at UNIS in 2015. Altogether, UNIS staff, fellows and students, and their families, comprise about $20 \%$ of the population of Longyearbyen. About half the staff and 


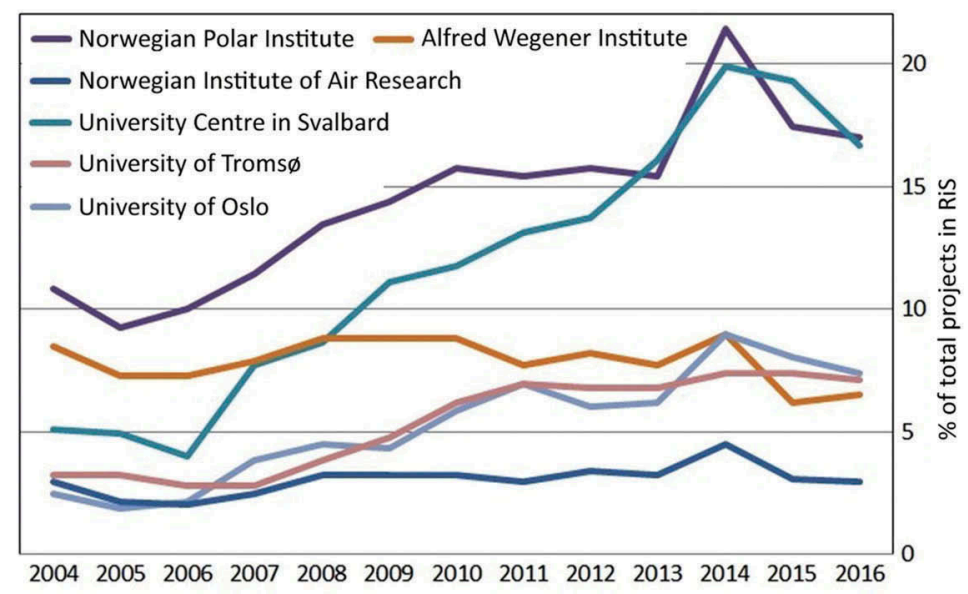

Figure 4. Development of number of research projects registered in the Research in Svalbard (RiS) database.

nearly $65 \%$ of the students come from outside Norway. The total budget of UNIS in 2016 was about 200 million NOK, and about half of the budget for direct costs is spent locally.

UNIS is set up for field-based research and education, with a well-functioning logistics unit that can equip staff and students for outdoor activities on land, on ice, or at sea at any time of the year. UNIS operates the Kjell Henriksen Observatory at Breinosa for observations and measurements in the upper and middle atmosphere. The UNIS $\mathrm{CO}_{2}$ Lab facility in Adventdalen has been used to explore the underground strata and assess the possibility of storing liquid $\mathrm{CO}_{2}$ in sealed and permeable sandstone formations (Sand et al. 2014).

UNIS is open to students matriculated at Norwegian universities who have completed one year of university education in natural science subjects, and who want an Arctic profile in biology, geology, geophysics or technology. A cooperation agreement between UNIS and the Norwegian universities ensures that UNIS courses complement those offered on the mainland. The opportunity to take courses at UNIS is promoted to students at the Norwegian universities, and courses completed at UNIS give full academic credit. Through this arrangement, UNIS is regarded as the common Arctic institute of the Norwegian universities. UNIS is also open to students coming directly from abroad, provided they fulfil the admission criteria; such students are matriculated at UiT, in Tromsø.

The NPI has a branch with about 10 permanent staff members at the SSC in Longyearbyen. NPI has a mandate as a research-based management organization, and acts as an advisor in polar environmental issues to the Ministry of Climate and Environment and to the Governor of Svalbard. NPI runs terrestrial, marine and atmospheric environmental monitoring programmes. In the light season (March-October) scientists and technical staff from the NPI's headquarters in Tromsø are active in Svalbard (Fig. 2). In 2014, NPI's total research activity in Svalbard constituted nearly 60 person-years (Fig. 3), with research effort rather evenly distributed between Ny-Ålesund (13 of 59 person-years), Longyearbyen (23 of 59 person-years) and other areas in and around Svalbard (23 of 59 person-years).

The largest universities on the Norwegian mainland - the University of Oslo, the UiT, the University of Bergen and the Norwegian University of Science and Technology - have substantial research activity in Svalbard (Figs. 3, 4). The total research activity of these universities (about 115 person-years) is approximately equivalent to that of UNIS and the NPI together (122 person-years). Many other Norwegian research organizations also have research activities in Svalbard, totalling about 45 person-years (Fig. 3). The research activities of the universities and many other research institutes are mainly undertaken as time-limited campaigns rather than requiring permanent staff residing in Svalbard.

A branch of the Research Council of Norway, SSF is employs three permanent staff members in Longyearbyen and has offices in SSC. The SSF's mandate is to coordinate research in Svalbard, to stimulate research cooperation and to administer the database Research in Svalbard. To obtain permission to go out in the field in Svalbard for research purposes, projects must first be registered in RiS. Research and research cooperation are stimulated through annual Arctic Field Grants and Strategic Grants through which SSF allocates about 5 million NOK for research activities in Svalbard. SFF calls upon all major research operators in Svalbard for coordination meetings twice a year.

SIOS is a project financed by the Research Council of Norway with the aim of establishing an independent organization in the SSC that would coordinate access to stations, observation units and databases for research purposes in Svalbard. SIOS will develop a 
knowledge centre to compile the information gathered from the substantial but rather fragmented research activity in Svalbard. Research organizations from about 10 countries are members of SIOS. In 2016 SIOS employed four staff members with permanent addresses in Longyearbyen.

\section{Arctic field stations}

Eleven institutions have established Arctic field stations in Ny-Ålesund (Table 1). The research activities in Ny-Ålesund are coordinated by the $\mathrm{Ny}$-Ålesund Science Managers Committee. In the summer season, there are scientists at all the stations and the village is full of activity. The NPI's Sverdrup Station, the Zeppelin Observatory, the Norwegian Mapping Authority's station and the joint French-German Arctic Research Base have small permanent staffs to enable measurements and observations also in winter. A record 14501 research days were logged in $\mathrm{Ny}$ Ålesund in 2014 (SSF 2017).

Russian research in Barentsburg dates back to the 1960s. The Russian Academy of Sciences and other Russian research institutes have laboratories and units in Barentsburg. A rather small group oversees the facilities in winter, and activity appears to increase in summer.

For several decades research has been conducted at the Stanislaw Siedlecki Polish Polar station in Hornsund, mainly in geophysical disciplines. A team of about 10 staff members operate the station through the winter, and in summer the activity can more than double.

At Hopen and Bjørnøya there are manned stations operated by the Meteorological Institute of Norway with four to six staff members working on six-month contracts. Their mandate is regular meteorological observations.

\section{Government policy for research and higher education in Svalbard}

A 2009 white paper presented to the Storting highlighted research and higher education as key elements in Norwegian activities in Svalbard (NMJ 2009). The government outlined its desire for the further development of Svalbard as a platform for international research, higher education and environmental monitoring, with Norwegian polar research taking a leading role. In 2016, the Norwegian government presented its updated policy for Svalbard (NMJ 2016). This gave research and higher education an even more pronounced role in the government's Svalbard policy. To promote the better utilization of the research possibilities in Svalbard, the white paper outlined actions to optimize resource use, strengthen coordination and cooperation, prioritize scientific activities, improve research quality, strengthen research leadership, strengthen the scientific bases for higher education and provide open access to data, while minimizing negative environmental impact.

One of the most important actions proposed in the white paper (NMJ 2016) is that UNIS, in cooperation with the Norwegian universities, develops further to make use of the unique opportunities offered by its location and strives to reach a 50:50 balance between Norwegian and foreign students. The government proposes to prolong its prioritization of polar research, especially in Svalbard, to enhance the volume and quality of Norwegian research in Svalbard and to stimulate use of the $\mathrm{Ny}$-Ålesund facilities by Norwegian scientists. Increased international cooperation is also suggested. SIOS is intended to become a subsidiary company under UNIS, and the SSF will be developed further. The NPI will be given overall responsibility for the operative implementation and follow-up of the new strategy for the research village of $\mathrm{Ny}$-Ålesund, and the ownership of Kings Bay will be transferred to the Ministry of Climate and Environment.

This is the most attention that research and higher education have been given in government white papers about Svalbard, and the priorities suggested by the government strongly underline the importance of these activities in Norwegian Svalbard policy in the years to come. As expected, the document signals further development of UNIS and indicates that an even closer cooperation with the mainland universities is needed to reach the objective of attracting more Norwegian students to Svalbard. The ongoing restructuring of higher education in Norway, where university colleges are merging with neighbouring universities, will give a larger student base to recruit from. The clear prioritization of polar research, especially in Svalbard, further stimulation of the Ny-Ålesund facilities and the desire for more international cooperation signal the importance of research in Norway's Svalbard policy. An evaluation of Svalbard research, and development of an overall strategy, will be important tools, and in these matters the Research Council of Norway can build on the Overall policy for Norwegian polar research developed a few years ago (Research Council of Norway 2014). There has been some controversy about the proposal that the NPI should be in charge of prioritizing research in $\mathrm{Ny}-$ Ålesund, but as a management body under the Ministry of Climate and Environment, the NPI is an organization with competence and experience in such matters. Moving the responsibility for the Norwegian State's ownership of Kings Bay to the Ministry of Climate and Environment will facilitate the coordination of Norwegian interests in $\mathrm{Ny}$ - 
Ålesund since the NPI and Kings Bay will be under the same ministry.

\section{Future prospects for academia in Svalbard}

Under the provisions of the Svalbard Treaty, many nations have taken the opportunity to establish Arctic research stations and facilities in Svalbard, either in their own settlements, as in Barentsburg or Hornsund, or in Ny-Ålesund, which the Kings Bay company has managed. Most probably, these foreign research stations will be kept running according to the agreements made with Norwegian authorities when the stations were established. With the current interest in Arctic research, it is to be expected that activities at these stations will remain at the present level for the foreseeable future and will contribute to the continuation of the settlement of Ny-Ålesund. Barentsburg and Hornsund are also expected to be maintained as settlements.

The Strategic business plan for Svalbard (Svalbard Business Association 2014) specifically states that UNIS has the potential to double its activity. The UNIS board and administration have outlined to the Ministry of Education and Research how such a development could be based on strengthening the existing thematic areas, adding new thematic areas such as Arctic safety, climate change and energy transfer, tourism and selected topics in the humanities and social sciences. A building Phase III for SSC is also argued for.

Gjerdrem and Fagernes (2016) were given a mandate to suggest ways to improve the organization of the units under the Ministry of Education and Research. They recommended that UNIS become an independent management organization (Gjerdrem \& Fagernes 2016). Gjerdrem and Fagernes (2016) argued that a strategically important organization such as UNIS should not continue as a limited shareholder company but rather as a unit directly under the Ministry of Education and Research. With an increasingly important role for UNIS in anchoring Norwegian settlement in Svalbard, such a development in the status of the organization should be welcomed. This will eventually raise UNIS to the same management level as the mainland Norwegian universities.

A prerequisite for working at UNIS is that the employee lives in Longyearbyen. UNIS provides housing at standard rates. The employee pays taxes $-15.8 \%$ of net income - to the Norwegian authorities in Longyearbyen at a rate that compares favourably to tax rates elsewhere in Norway. If the employee stays in Longyearbyen for fewer than 187 days per year, the local tax office can decide that the employee shall be taxed according to the rules for mainland Norway or his/her home country. Thus the employment criteria at UNIS and Svalbard's local tax regulations are incentives for UNIS employees to reside in Longyearbyen. Other incentives are day care, a good school, first-class telecommunications, excellent opportunities for indoor and outdoor sports, a rich cultural scene and the spectacular Arctic nature.

As a part of the ongoing process of merging institutions of higher learning in mainland Norway, the UiT proposed (Anonymous 2015) incorporating UNIS and developing a campus in Longyearbyen. But UNIS is a national concern, and would probably not benefit from becoming part of a regionally based university that has its main activities on the Norwegian mainland (Misund 2015). Rather, UNIS should be further developed along the lines of the basic model that relies on close cooperation on an equal basis with all the Norwegian universities.

Strengthening other research organizations such as the NPI, SIOS and SSF locally in Longyearbyen may also contribute to a stable community if new staff members are required to reside permanently in the town. Strengthening research in Svalbard in general would not necessarily contribute to a stable familybased community if more researchers come to Svalbard for a limited period, for instance, to do fieldwork in summertime. Ny-Ålesund functions well as an Arctic outpost station community (i.e., without families), and enables researchers from many countries to visit briefly, mostly in summer. A challenge for Norwegian authorities is to stimulate business activities in Longyearbyen so that the town does not end up as a larger version of $\mathrm{Ny}$-Ålesund.

Even if research and education activities in Longyearbyen are doubled, as suggested by the Strategic business plan for Svalbard (Svalbard Business Association 2014), through strengthening organizations such as UNIS, NPI, SSF and SIOS, I am afraid this will not compensate for the loss of employment in coal mining. SNSK scaled down from more than 400 employees in 2014 to fewer than 100 in 2016. The number of jobs lost in the coal mining industry in the years 2014-16 is therefore of the same order of magnitude as the total Norwegian research effort in Svalbard of about 303 person-years in 2014. Business activities such as tourism, logistics, various services and possibly industrial activities related to fisheries (Misund 2014; Misund et al. 2016) have to be developed further if the population numbers in Longyearbyen are to be maintained.

Carrying on with activities in Sveagruva, which is an industrial site only, will be an even more challenging task when coal mining closes down. UNIS uses the Sveagruva facilities, approximately 1200 person-days per year, for field excursions and research purposes. The site is open to other organizations as well, but so far such use is rather limited. SNSK, together with SINTEF and UNIS, 
has launched an initiative called the Svea Arctic Research Institute, but the response and support so far have been meagre. For activities related to Arctic engineering, Sveagruva is an interesting site: SNSK operates a harbour, an air field and accommodation facilities, and gives access to its coal mines. Sea ice forms regularly during the winter on Van Miijenfjorden, which is sheltered from the open sea by the island of Akseløya, making Svea well-sited for studies involving sea ice.

In the years to come, science and education will likely constitute the foundation of Norwegian settlement in Svalbard. The revised policy presented in the recent white paper on Svalbard (NMJ 2016) makes it apparent that the scientific profile of the main Norwegian settlements in the archipelago will evolve through continued development of $\mathrm{Ny}$-Ålesund as a clean site for environmental research, of Longyearbyen for higher education and science within a family town, and of Sveagruva as an arena for applied and industrial research in the Arctic.

\section{Acknowledgements}

NPI Director Jan Gunnar Winter gave valuable comments on the manuscript and the role of academia in the development of Svalbard. Janet Holmén gave valuable advice on how to improve the English text. Dr Dag W. Aksnes at the Nordic Institute for Studies in Innovation, Research and Education provided Fig. 3 and Dr Karoline Bælum at the Svalbard Science Forum provided Fig. 4.

\section{Disclosure statement}

No potential conflict of interest was reported by the author.

\section{References}

Aksnes D.W. \& Rørstad K. 2015. Norsk polarforskningforskning på Svalbard. Ressursinnsats og vitenskapelig publisering-indikatorer 2014. (Norwegian polar research-research in Svalbard. Resources invested and scientific publications-indicators 2014.) NIFU Report 37/2016. Oslo: Nordic Institute for Studies in Innovation, Research and Education.

Anonymous. 2014. Svalbard forskningspark. Etterevaluering, desember 2014. (Svalbard Science Park. Reevaluation, December 2014.) Trondheim: Norwegian University of Science and Technology.

Anonymous. 2015. Vil legge UNIS under Tromsø. (UNIS to be organized under Tromsø.) Svalbardposten 49, 12-13.

Arlov T. 2007. Svalbards historie. (The history of Svalbard.) Bergen: Fagbokforlaget.

Avango D., Hacquebord L., Aalders Y., de Haas H., Gustafsson U. \& Kruse F. 2011. Between markets and geo-politics: natural resource exploitation on Spitsbergen from 1600 to the present day. Polar Record $47,29-39$.

Bjørnsen H. \& Johansen S. 2014. Samfunns- og noeringsanalyse for Svalbard 2014. (Community and business analysis for Svalbard 2014.) NIBR Report 2014:26. Oslo: Norwegian Institute for Urban and Regional Research.

Gjerdrem S. \& Fagernes S.O. 2016. Kunnskapssektoren sett utenfra. Gjennomgang av organisering av de sentraladministrative oppgaver $i$ kunnskapssektoren. Rapport til Kunnskapsdepartementet 6. januar 2016. (The knowledge sector seen from the outside. Review of the organization of the central administrative tasks in the knowledge sector. Report to the Ministry of Education and Research 6 January 2016.) Oslo: Ministry of Education and Research.

Hacquebord L. \& Avango D. 2009. Settlements in an Arctic resource frontier region. Arctic Anthropology 46, 25-39.

Helgesen L.M., Holmén K. \& Misund O.A. (eds.) 2015. The ice is melting. Ethics in the Arctic. Bergen: Fagbokforlaget.

MacKeith P. 2006. Svalbard Research Centre, Norway. Architectual Record 03.2006, 112-119.

Misund O.A. 2014. Norwegian fisheries: technologically advanced, biologically sustainable and economically profitable. Marine Technology Society Journal 48, 17-23.

Misund O.A. 2015. UNIS er et nasjonalt anliggende. (UNIS is of national concern.) Svalbardposten 50, 51.

Misund O.A., Heggland K., Skogseth R., Falck E., Gjøsæter H., Sundet J., Watne J. \& Lønne O.J. 2016. Norwegian fisheries in the Svalbard zone since 1980. Regulations, profitability and warming waters affect landings. Polar Science 10, 312-322.

NMJ (Norwegian Ministry of Justice and Public Security). 2009. Svalbard. Stortingsmelding 22. (Svalbard. White Paper to Parliament 22.) Oslo: Norwegian Ministry of Justice and Public Security.

NMJ (Norwegian Ministry of Justice and Public Security). 2016. Svalbard. Stortingsmelding 32. (Svalbard. White Paper to Parliament 32.) Oslo: Norwegian Ministry of Justice and Public Security.

Research Council of Norway. 2014. Norsk polarforskning. Forskningsrådets policy for 2014-2023. (Norwegian Polar Research. The policy of the Norwegian Research Council for 2014-2023.) Oslo: Research Council of Norway.

Reymert P.K. \& Moen O. 2015. Fangsthytter på Svalbard 1794-2015. (Hunting cabins in Svalbard 1794-2015.) Longyearbyen: Svalbard Museum.

Sand G., Braathen A. \& Olaussen S. 2014. Longyearbyen $\mathrm{CO}_{2}$ lab-tales of research and education. Norwegian Journal of Geology 94, 77-82.

SSF (Svalbard Science Forum) 2017. Ny-Ålesund. Accessed online at http://www.forskningsradet.no/prognett-ssf/ NyAlesund/1254001110293 on 07 February 2017.

Svalbard Business Association. 2014. Strategisk noeringsplan for Svalbard. (Strategic business plan for Svalbard.) Longyearbyen: Longyearbyen Town Council and Svalbard Business Association. 